\title{
Tsunami Modelling Araound Lombok, Indonesia
}

\author{
Indriati Retno Palupi ${ }^{1}$ and Wiji Raharjo ${ }^{1}$ \\ Geophysical Engineering, UPN “Veteran” Yogyakarta \\ Email : inder13101986@gmail.com
}

\author{
Article Information \\ Received: \\ 6 October 2020 \\ Received in revised form: \\ 2 November 2020 \\ Accepted: \\ 5 December 2020
}

Volume 2, Issue 2, December 2020

pp. $64-67$

(C) Universitas Lampung

\begin{abstract}
Lombok earthquake in 2018, raised many failure of facilities that impact to human life. The earthquake was unique, started with mainshock that did not predict by scientist with hypocenter located in Flores Fault in the north of Lombok Island. In 1992, tsunami recorded in Lombok with the hypocenter also in Flores Fault. Based on the information, earthquake in Flores Fault can trigger tsunami. Beside Flores Fault, subduction zone in the south of Lombok is also can be earthquake source and it is not impossible can trigger the tsunami. The purpose of this research is to modeled the tsunami both it come from earthquake in Flores Fault and the subduction zone with magnitude 7.8. Numerical method is used to modelled it and the result is the height and velocity of tsunami is $11 \mathrm{~m}$ and $720 \mathrm{~km} / \mathrm{hours}$ for Flores Fault and $9 \mathrm{~m}$ and $450 \mathrm{~km} / \mathrm{hour}$ for subduction Zone
\end{abstract}

Keywords: Lombok, earthquake, tsunami, Flores Fault, subduction zone

\section{INTRODUCTION}

L ombok is one of tourism destination in Indonesia besides Bali. There are several beautifull beach tourism ordered by Lombok Island. Its location is close to Bali, so Lombok is an strategic place for tourist to enjoy the panorama. Although Lombok has beautifull sight, it also has disaster potential like earthquake and tsunami. Earthquake in 2018 located in Flores Fault for the example, damaged several facilities around Lombok. Actually, the earthquake in Lombok in 2018 is unique. It is started by foreshcok, then followed by mainshock and the artershock [1]. This fenomena is rarely happened. The Flores Fault earthquake also can triggered the tsunami. Based on BMKG information, in 1992 there was tsunami in Lombok that triggered by earthquake in Flores Fault [2].

The tsunami usually triggered by reverse fault focal mechanism of earhquake although in some event like tsunami in Palu in 2018 triggered by strike slip fault (the probability is low). Beside earthquake, volcano eruption in the sea also can affect the tsunami. For the example, tsunami affected by Krakatau eruption in 1883 and 1815 . Tsunami triggered by volcano eruption usually caused by the erotion from some part of volcanic body [3].

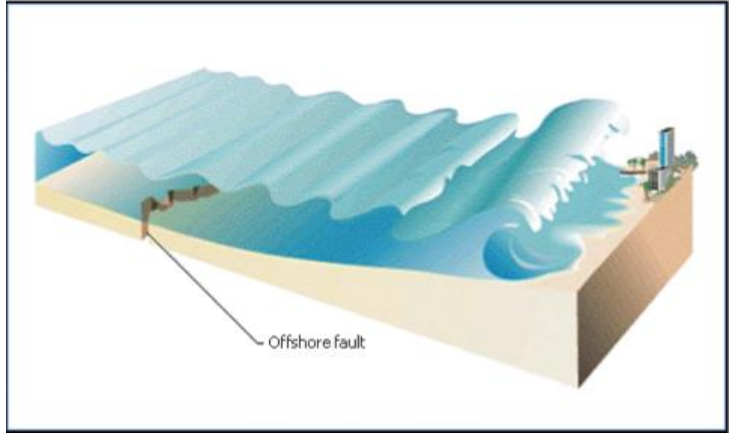

Figure 1. Ilustration of tsunami [3]

Simulation of tsunami displayed by the height and velocity by assumed the location of hypocenter araound Lombok can give some descriptions about the danger level of the tsunami. The simulation is done by apply some mathematic and numerical equation to be modelled by using Matlab and Python. Matlab and Python is choosen because they have simple coding and can covering the big data.

\section{METHODS}

Modelling tsunami need some information or data about the location and magnitude of hypocenter that triggered the tsunami and the bathimetry around research area. It is needed to calculate the velocity wave 
of tsunami. First, large area affected by the focal mechanism must be calculated to know how much the sea water volume moved by the earthquake. Then, using mechanics energy principal, velocity and the height of tsunami wave is modelled by Well and Coppersmtih (1994) and Lay and Wallace in [4].

$$
\begin{aligned}
& \log L=0.63 M-2.86 \\
& \log W=0.41 M-1.61 \\
& \log D=0.29 M-1.84 \\
& v=\sqrt{g h}
\end{aligned}
$$

Where $\mathrm{L}$ and $\mathrm{W}$ are fault's length and wide, $\mathrm{M}$ is magnitude and $\mathrm{D}$ the deformation in seabed. For equation (4), $\mathrm{v}$ is velocity in $\mathrm{m} / \mathrm{s}, \mathrm{g}$ is gravity acceleration in $\mathrm{m} / \mathrm{s}^{2}$ and $\mathrm{h}$ is the depth in $\mathrm{m}$.

The principal of energy mechanics, there are tranfsormation from the energy kinetics to energy potential and the opposite is the same. Based on the equation (4), the velocity is proportional with the depth. So, in the beach, the depth is shallow and the velocity will be decreased. As a result, the height of the tsunami height will increase. The height is calculated using equation (5) from Bryant (2008) in [4].

$$
H_{n}=\sqrt{\frac{v_{n-1}}{v_{n}}} \sqrt{\frac{b_{n-1}}{b_{n}}} H_{n-1}
$$

where $\mathrm{H}_{\mathrm{n}}$ and $\mathrm{H}_{\mathrm{n}-1}$ are height in $\mathrm{n}$ and $\mathrm{n}-1, \mathrm{v}_{\mathrm{n}}$ and $\mathrm{v}_{\mathrm{n}-1}$ are the velocity in $n$ and $n-1$ and $b_{n}$ and $b_{n-1}$ are the distance of tsunami wave in $\mathrm{n}$ and $\mathrm{n}-1$. Anyway, the equation (1) to equation (5) are simple way to modelling the tsunami. The other way to modelling tsunami can use partial differential equation based on wave equation of mathematical model [5].

\section{RESULTS AND DISCUSSIONS}

Matlab and Python is used to calculate the height and velocity of tsunami wave. Velocity wave figure in the form of maps by using basemap module in Python, while the height figure by the graph. The hypocenter assumed located in Flores Fault and the subduction zone with magnitude 7.8 .

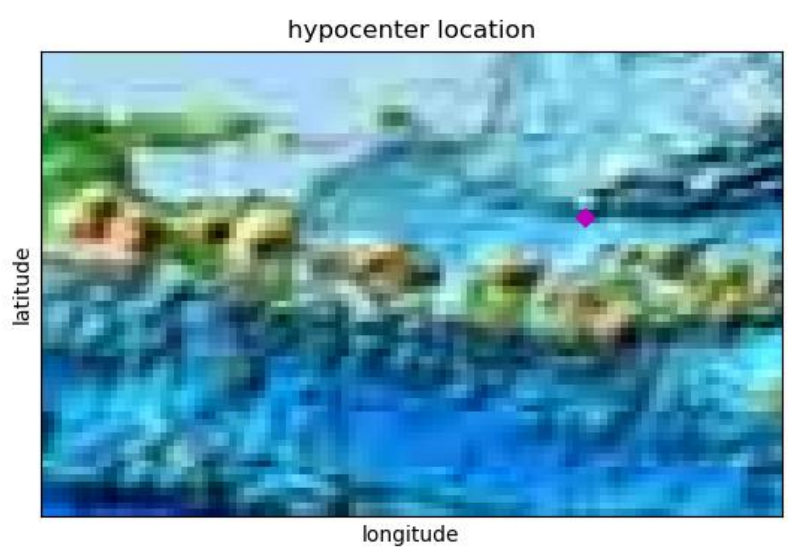

(a)



(b)

Figure 2. Hypocenter location (a) Flores Fault; (b) Subduction zone

The location of hypocenter is choosen for the simulation because both of them is potential to be earthquake source. Flores Fault is the source of earthquake triggered the tsunami in 1992 and also the source of earthquake in 2018. In the south of Lombok, there is subduction zone. The subduction zone is confluence of two plates, Australia and Eurasia.

Using bathimetry data around research area, height and velocity of tsunami is modeled by equation (1) to (5). The model can be seen Figure 3 and Figure 4. 


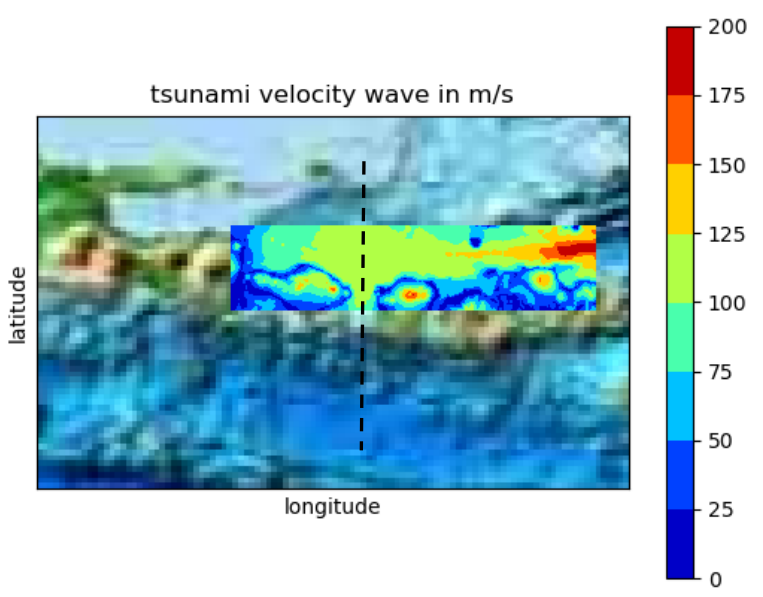

(a)
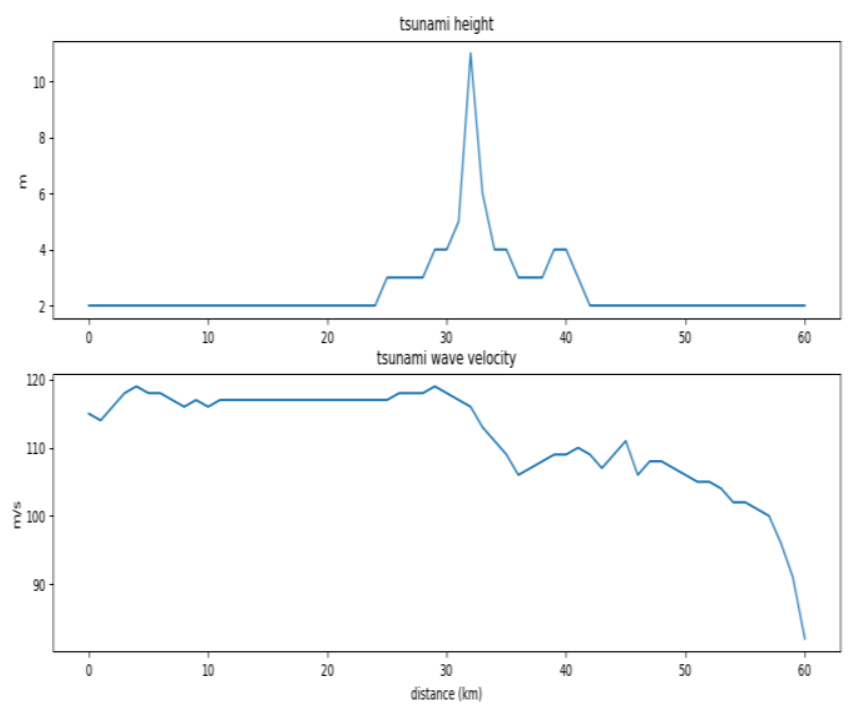

(b)

Figure 3. (a) Velocity model of tsunami with hypocenter in Flores fault. The colorbar scale is in $\mathrm{m} / \mathrm{s}$; (b) tsunami height in the dashed line of (a) from south to north

Based on Figure 3 (a), it can be seen that the velocity of tsunami from Flores fault as the earthquake source has range from 0 to $200 \mathrm{~m} / \mathrm{s}$ or 0 to $720 \mathrm{~km} / \mathrm{s}$. Velocity dominant in Lombok island is $125 \mathrm{~m} / \mathrm{s}$ or 450 $\mathrm{km}$ with the height reach to $10 \mathrm{~m}$. It is a big velocity and height value for tsunami wave and can destroy anything trhough by it.

Velocity of tsunami wave with the hypocenter located in subduction zone has bigger value than Flores Fault. It's value reach to $240 \mathrm{~m} / \mathrm{s}$ or $864 \mathrm{~km} / \mathrm{s}$. It is because coverage area of water is larger than in Flores fault. While, the height is more than $8 \mathrm{~m}$ and more variying than in Flores fault. In both of model, the velocity decrease with the increase of tsunami height.

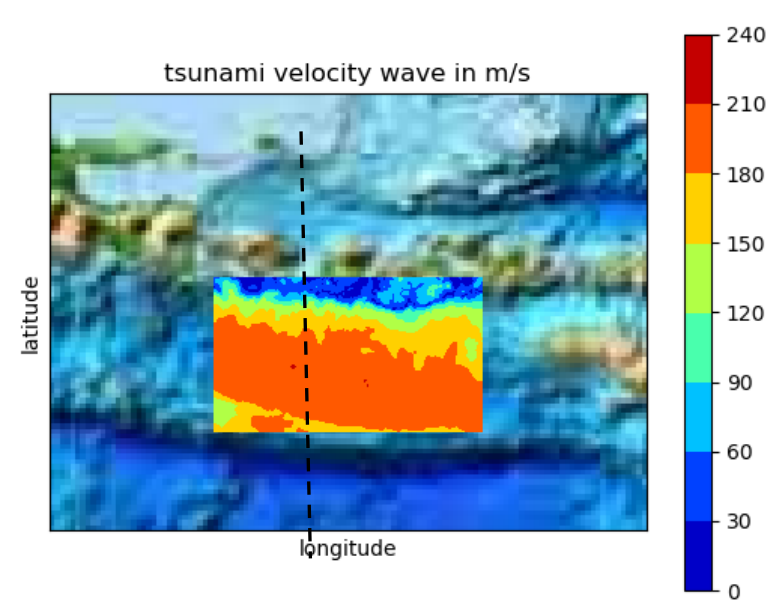

(a)
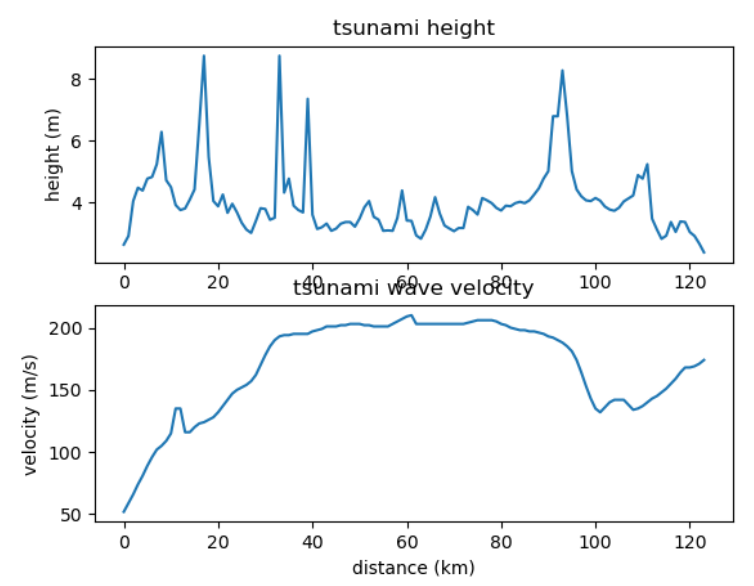

(b)

Figure 4. (a) Velocity model of tsunami with hypocenter in subduction zone. The colorbar scale is in $\mathrm{m} / \mathrm{s}$; (b) tsunami

height in the dashed line of (a) from south to north

The dashed line is choosen as a sample to describe the height og the tsunami. It include to West Lombok region which has a lot of tourism destination of a beach. There are many fasilities there that sorrowfull of having damaged caused by tsunami. So the model is usefull as a description for the mitigation of tsunami.

\section{CONCLUSIONS}

Tsunami wave can be modelled or simulate in velocity and height by using some mathematical equation using hypocenter location and some bathimetry data. Assumed the hypocenter located in Flores fault and subduction zone with magnitude 7.8 After the length, wide and deformation parameter calculated, the height and velocity can calculated by using energy mechanics principal, the transformation 
from energy kinetics to potential or the opposite. The velocity of tsunami that come from earthquake in subduction zone is bigger than Flores fault, but the height is smaller. It is caused by coverage area is larger in the subduction zone than Flores fault. Anyway both of them are potential to destroy the facilities through by the tsunami.

\section{ACKNOWLEDGMENT}

The author of this research gratefully acknowlegment to LPPM UPN "Veteran" Yogyakarta that supporting this research so it can give the best description model of the tsunami for the mitigation.

\section{REFERENCES}

[1] Irsyam, Mashyur, N. R. Hanifa and D. Djarwadi, "Kajian Rangkaian Gempa Lombok Provinsi Nusa Tenggara Barat," Tim pusat studi gempa nasional Pusat Litbang Perumahan dan Pemukiman, 2018.

[2] Triyono, Rahmat, T. Prasetya, Daryono, S. D. Anugrah, A. Sudrajat and U. Setiyono, "Katalog
Tsunami Indonesia Tahun 416-2018," Pusat Gempa Bumi dan Tsunami Kedeputian Bidang Geofisika, 2019.

[3] N. T. Sugito, "Tsunami," Universitas Pendidikan Indonesia, Bandung.

[4] Sumtaki, M. Inggried, G. P. H. J. Seni and Tingkukut, "Simulasi Penjalaran Gelombang Tsunami di Sofifi-Tidore Kepulauan Maluku Utara sebagai Upaya Mitigas Bencana," Jurnal MIPA UNSRAT, vol. 6, no. 1, pp. 83-87, 2017.

[5] Dutykh and Denis, "Mathematical Modelling of Tsunami Waves," Centre de Mathematiques. 